Primljen / Received: 13.7.2017. Ispravljen / Corrected: 7.2.2018.

Prihvaćen / Accepted: 22.3.2018. Dostupno online / Available online: 10.9.2018.

\section{Evaluation of methods for predicting axial capacity of jacked-in and driven piles in cohesive soils}

Authors:

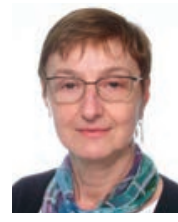

Assoc.Prof. Mirjana Vukićević, PhD. CE University of Belgrade

Faculty of Civil Engineering

mirav@grf.bg.ac.rs

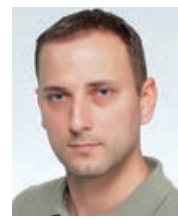

Miloš Marjanović, MCE

University of Belgrade

Faculty of Civil Engineering

mimarjanovic@grf.bg.ac.rs

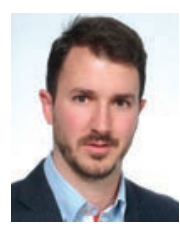

Veljko Pujević, MCE

University of Belgrade

Faculty of Civil Engineering

vpujevic@grf.bg.ac.rs

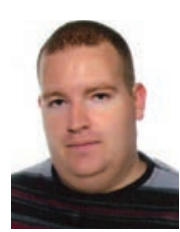

Nikola Obradović, MCE

University of Belgrade

Faculty of Civil Engineering

nobradovic@grf.bg.ac.rs

\section{Mirjana Vukićević, Miloš Marjanović, Veljko Pujević, Nikola Obradović}

Preliminary report

\section{Evaluation of methods for predicting axial capacity of jacked-in and driven} piles in cohesive soils

This paper presents the evaluation of methods for predicting the ultimate axial bearing capacity of single piles based on the cone penetration test (CPT) results, and the evaluation of static methods based on the effective and total stress analysis. Seventeen jacked-in MEGA piles and eight Franki piles of different lengths are considered. The results show that the Bustamante \& Gianeselli (LCPC) method is the most appropriate for the studied geotechnical conditions and pile types.

\author{
Key words: \\ jacked-in MEGA pile, Franki pile, pile axial capacity, static load test
}

Prethodno priopćenje

Mirjana Vukićević, Miloš Marjanović, Veljko Pujević, Nikola Obradović

Ocjenjivanje metoda za predvidanje osne nosivosti utisnutih i zabijenih pilota u koherentnom tlu

$\mathrm{U}$ radu je prikazano ocjenjivanje metoda za predviđanje granične osne nosivosti pojedinačnih pilota na bazi rezultata statičkog penetracijskog pokusa (CPT), te ocjenjivanje statičkih metoda baziranih na analizi efektivnog i ukupnog naprezanja. Analizirano je sedamnaest utisnutih MEGA pilota i osam Franki pilota različitih dužina. Dobiveni rezultati pokazuju da je, među izravnim CPT metodama, za analizirane geotehničke uvjete i tipove pilota najbolja metoda koju predlažu Bustamante i Gianeselli (LCPC).

Ključne riječi:

utisnuti MEGA pilot, Franki pilot, osna nosivost pilota, ispitivanje statičkim opterećenjem

Vorherige Mitteilung

Mirjana Vukićević, Miloš Marjanović, Veljko Pujević, Nikola Obradović

Beurteilung der Methode zur Vorhersage der Tragfähigkeit der Achse der eingestanzten und eingerammten Pfeiler im kohärenten Boden

In der Abhandlung werden die Beurteilung der Methode zur Vorhersage der Grenztragfähigkeit der Achse einzelner Pfeiler aufgrund der Ergebnisse des statischen Penetrationsversuchs (CPT) sowie die Beurteilung der statischen Methoden basierend auf der Analyse der effektiven und gesamten Spannung dargelegt. Analysiert wurden siebzehn eingestanzte MEGA Pfeiler und acht Franki Pfeiler unterschiedlicher Länge. Die erhaltenen Ergebnisse zeigen, dass die direkte CPT Methode die beste ist, die von Bustamente und Gianeselli (LCPC) vorgeschlagen wird, und dies ist auch die geeignetste Methode für die Analyse geotechnischer Bedingungen und Pfeilertypen.

Schlüsselwörter:

eingestanzter MEGA Pfeiler, Franki Pfeiler, Tragfähigkeit der Achse des Pfeilers, Untersuchung durch statische Belastung 


\section{Introduction}

Pile foundations are most frequently used in cases when surface layers of soil are characterized by low bearing capacity. In the design of pile foundations, the evaluation of axial pile capacity directly affects the stability and load capacity of the entire structure. The pile axial capacity is calculated as the sum of the pile base capacity $\left(Q_{b}\right)$ and pile shaft capacity $\left(Q_{s}\right)$.

Two groups of prediction methods are used in engineering practice for estimation of the axial pile capacity. The first group includes the total stress analysis ( $\alpha$-method) and the effective stress analysis ( $\beta$-method). In these methods, shear strength parameters for fine grained soils are usually obtained from both laboratory and in-situ tests, while the parameters for coarse grained soils are mostly correlated from the results of in-situ penetration tests. The second group of methods is directly based on the results of in-situ tests, mostly CPT (and CPTu), SPT and, more recently, DMT. Compared to other in-situ tests, main advantages of CPT test lie in its simplicity, speed and costs of execution, continuous sounding record with depth, and in the possibility of installing additional sensors. Most CPT methods were developed in 1980s. They are based on the hypothesis that the cone penetrometer represents a micro pile whose tip resistance $\left(q_{c}\right)$ and sleeve friction $\left(f_{s}\right)$ are measured. These methods are empirical, formulated by comparing the CPT test results with pile capacities measured in various geotechnical conditions and for various pile types. By using the CPT methods, soil sampling and laboratory testing become unnecessary, and the time required for preliminary estimation of pile load is reduced significantly. Also, by excluding the soil sampling phase, the effect of sample disturbance on shear strength parameters is eliminated.

Before choosing an appropriate method for calculation of load capacity, the applicability of methods for specified geotechnical conditions and pile type should be carefully considered. Many researchers have dealt with evaluation of direct methods, CPT methods in particular. Some previous studies are listed as follows: Briaud \& Tucker [1] evaluated six CPT methods using 98 pile load test results, Sharp et al. [2] evaluated three SPT and two CPT methods based on 28 pile load tests, Eslami and Fellenius [3] reviewed evaluation results for six CPT (CPTu) methods applied to 102 case histories, Abu-Farsakh and Titi [4] evaluated eight CPT methods by comparing predicted pile loads with 35 pile load tests of driven friction piles. To evaluate acceptability of these methods, and to enable their further improvement, it is very important to permanently update the database of static load test results for various geotechnical conditions and pile types, which was the motivation for writing this paper.

The applicability of ten existing methods for predicting the ultimate load capacity of 25 piles, mainly in fine grained soils, is evaluated in this paper. Two pile types were considered: driven Franki and jacked-in MEGA piles. The measured load capacities $\left(Q_{m}\right)$ for Franki piles were obtained from static load tests, while the final measured force during pile jacking was used as ultimate bearing capacity for MEGA piles (due to fact that the jacking of each pile is, in fact, a pile load test). Eight direct CPT methods (Bustamante \& Gianeselli (LCPC) [5], Schmertmann [6], De Ruiter \& Beringen [7], Tumay \& Fakhroo [8], Penpile [9], Philipponnat [10], Price \& Wardle [11], Aoki \& De Alencar [12]) and two static $\beta$-methods (where pile base capacity is calculated according to Meyerhof [13] and Hansen [14]), were selected and evaluated. The static $\alpha$-method (API method) [15] was additionally evaluated for two Franki piles where undrained shear strength parameters were available, in order to analyse the influence of draining conditions on prediction results.

Statistical analysis was performed in order to evaluate and rank the aforementioned methods. Measured pile capacities $\left(Q_{m}\right)$ were compared with estimated values $\left(Q_{p}\right)$, and $Q_{p} / Q_{m}$ ratios were calculated. Statistical assessment was conducted based on the best fit lines, arithmetic mean, standard deviation, and log-normal distribution of the $\mathrm{Q}_{\mathrm{p}} / \mathrm{Q}_{\mathrm{m}}$ ratios.

\section{Pile capacity prediction methods}

The ultimate axial capacity of a pile (Q) is the sum of the pile base capacity $\left(\mathrm{Q}_{\mathrm{b}}\right)$ and pile shaft capacity $\left(\mathrm{Q}_{\mathrm{s}}\right)$ :

$$
Q=Q_{b}+Q_{s}=q_{b} A_{b}+\sum_{i=1}^{n} q_{s, i} A_{s, i}
$$

where $q_{s, i}$ is the unit skin friction of the soil layer $i, A_{s, i}$ is the pile shaft area interfacing with layer $i$, and $n$ is the number of soil layers along pile shaft. A summary of the CPT methods evaluated in this paper is given in Table 1. Additionally, summary of static methods is given in Table 2.

\section{Characteristics of investigated piles and load capacity test procedure}

The first group of investigated piles were concrete MEGA piles, constructed as a part of two rehabilitation projects - Faculty of Chemistry in Belgrade and Church in Zemun, Serbia [1719]. The MEGA pile is a prefabricated jacked-in pile consisting of short elements made of steel or concrete. MEGA piles are often used as an alternative to classic underpinning in medium to soft soils. By measuring the jacking force during pile installation, the pile is "tested" and the ultimate bearing capacity is obtained. A total of 17 piles that were very close to the CPT tests were selected. CPT tests were executed earlier during the project design phase. Squared cross section (400 x $400 \mathrm{~mm}$ ) piles were selected for the Faculty of Chemistry rehabilitation project, with lengths ranging from 6.25 to 9.85 $\mathrm{m}$, while $10 \mathrm{~m}$ long circular (Ø323) MEGA piles were chosen for the church in Zemun. Jacking forces $\left(Q_{m}\right)$ recorded for the Faculty project ranged from 932 to $1765 \mathrm{kN}$, while those for the Church project were $770 \mathrm{kN}$. 
Table 1. Summary of direct CPT methods used for prediction of ultimate pile capacity

\begin{tabular}{|c|c|c|}
\hline Method & $q_{b}$ & $q_{s}$ \\
\hline $\begin{array}{c}\text { Bustamante \& } \\
\text { Gianeselli (LCPC) }\end{array}$ & $\begin{array}{c}q_{b}=k_{b 1} q_{c a} \\
\mathrm{q}_{\mathrm{ca}} \text { - average cone tip resistance of zone ranging from 1.5D } \\
\text { below the pile tip to } 1.5 \mathrm{D} \text { above the pile tip } \\
\mathrm{k}_{\mathrm{b} 1}=0.15-0.60 \text { - bearing factor depending on the soil } \\
\text { type, pile type and value of cone tip resistance } \mathrm{q}_{c}\end{array}$ & $\begin{array}{c}q_{s}=\frac{1}{\alpha_{1}} q_{c} \leq q_{s, \max } \\
\alpha_{1}=30-200-\text { coefficient depending on soil type, pile type } \\
\text { and value of cone tip resistance } q_{c} \\
q_{s, \max }-\text { maximum value of unit shaft friction depending on soil } \\
\text { type, pile type and value of cone tip resistance } \mathrm{q}_{c}\end{array}$ \\
\hline Schmertmann & $\begin{array}{c}q_{b}=C_{1} q_{c a} \leq 15 \mathrm{MPa} \\
\mathrm{q}_{\mathrm{ca}}-\text { average cone tip resistance of zone ranging from } 8 \mathrm{D} \\
\text { above the pile tip to } 0.7 \mathrm{D} \text { or } 4 \mathrm{D} \text { below the pile tip } \\
\mathrm{C}_{1}=0.5-1.0 \text { - coefficient depending on OCR factor }\end{array}$ & $\begin{array}{c}q_{s}=k_{f} f_{s} \leq 120 \mathrm{kPa} \\
\mathrm{k}_{\mathrm{f} 1}=0.20-1.25-\text { coefficient for clay depending on pile materia } \\
\text { and sleeve friction }\end{array}$ \\
\hline $\begin{array}{l}\text { De Ruiter \& } \\
\text { Beringen }\end{array}$ & $\begin{array}{c}\text { For clay: } q_{b}=N_{c} S_{u} \leq 15 \mathrm{MPa} \\
\mathrm{N}_{\mathrm{c}}=9, \mathrm{~S}_{\mathrm{u}}=\mathrm{q}_{\mathrm{c}} / \mathrm{N}_{\mathrm{k}} \\
\mathrm{N}_{\mathrm{k}}=15-20^{*}-\text { correlation factor between cone tip } \\
\text { resistance } \mathrm{q}_{\mathrm{c}} \text { and undrained shear strength } \mathrm{S}_{\mathrm{u}} \\
\text { For sand: similar to Schmertmann }\end{array}$ & $\begin{array}{c}\text { For clay: } q_{S}=\alpha_{2} S_{u} \leq 120 \mathrm{kPa} \\
\alpha_{2}=0,5-1,0-\text { coefficient depending on OCR factor } \\
\text { For sand: } q_{s}=\min \left\{\begin{array}{l}f_{s} \\
q_{c} / 300 \\
120 \mathrm{kPa}\end{array}\right\}\end{array}$ \\
\hline $\begin{array}{l}\text { Tumay \& } \\
\text { Fakhroo }\end{array}$ & Similar to Schmertmann & $\begin{aligned} q_{s}= & k_{12} f_{s} \leq 72 \mathrm{kPa} \\
k_{12}= & 0,5+9,5 \mathrm{e}^{-90 \mathrm{f}_{\mathrm{s}}} \\
& \mathrm{f}_{\mathrm{s}} \mathrm{u} \mathrm{MPa}\end{aligned}$ \\
\hline Penpile & $\begin{array}{c}q_{b}=C_{2} q_{c} \leq 15 \mathrm{MPa} \\
C_{2}=0,2525 \text { for pile tip in clay } \\
C_{2}=0,12525 \text { for pile tip in sand }\end{array}$ & $\begin{array}{c}q_{s}=\frac{f_{s}}{1.5+14.47 f_{s}} \leq 120 \mathrm{kPa} \\
q_{s} i_{s} \text { u MPa }\end{array}$ \\
\hline Philipponnat & $\begin{array}{c}q_{b}=C_{3} q_{c} \leq 15 \mathrm{MPa} \\
C_{3}-\text { coefficient depending on soil type } \\
\text { (0.40 for sand, } 0.45 \text { for silt, } 0.50 \text { for clay) }\end{array}$ & 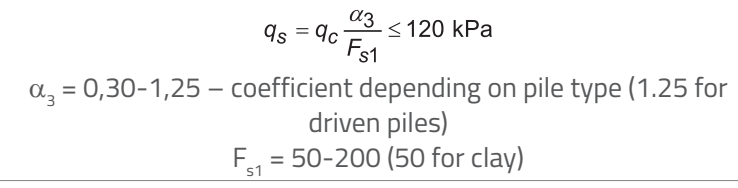 \\
\hline Price \& Wardle & $\begin{array}{c}q_{b}=C_{4} q_{c} \leq 15 \mathrm{MPa} \\
\mathrm{C}_{4}-\text { coefficient depending on pile type } \\
\text { (0.35 for driven piles) }\end{array}$ & $\begin{array}{c}q_{s}=\alpha_{4} f_{s} \leq 120 \mathrm{kPa} \\
\alpha_{4}-\text { coefficient depending on pile type } \\
\text { (0.53 for driven piles) }\end{array}$ \\
\hline $\begin{array}{l}\text { Aoki \& De } \\
\text { Alencar }\end{array}$ & $\begin{array}{c}\qquad q_{b}=\frac{q_{C}}{F_{b}} \leq 15 \mathrm{MPa} \\
\mathrm{F}_{\mathrm{b}}=1.75-3.50-\text { coefficient depending on pile type }\end{array}$ & $\begin{array}{c}q_{s}=q_{c} \frac{\alpha_{5}}{F_{s 2}} \leq 120 \mathrm{kPa} \\
\alpha_{5}=1.4-6 \%-\text { coefficient depending on soil type } \\
\mathrm{F}_{\mathrm{s} 2}=3.5-7-\text { coefficient depending on pile type }\end{array}$ \\
\hline
\end{tabular}

Table 2. Summary of static methods used for prediction of ultimate pile capacity

\begin{tabular}{|c|c|c|c|}
\hline Method & & $q_{b}$ & $q_{s}$ \\
\hline $\begin{array}{l}\text { Undrained loading } \\
\text { conditions } \\
\text { ( } \alpha \text {-method) }\end{array}$ & \multicolumn{2}{|c|}{$\begin{array}{c}q_{b}=N_{C} S_{u}+\sigma_{v} \\
N_{c}=9\end{array}$} & $\begin{array}{c}q_{s}=\alpha_{6} S_{u} \\
\alpha_{6}=1 \mathrm{za}_{\mathrm{u}} \leq 25 \mathrm{kPa} \\
\alpha_{6}=0,5 \mathrm{za} \mathrm{S}_{u} \geq 70 \mathrm{kPa} \\
\text { (interpolation for other } S_{u} \text { ) }\end{array}$ \\
\hline \multirow[b]{2}{*}{$\begin{array}{l}\text { Drained loading } \\
\text { conditions } \\
\text { ( } \beta \text {-method) }\end{array}$} & \multicolumn{2}{|c|}{$q_{b}=N_{c}^{*} c^{\prime}+\eta \sigma_{V}{ }^{\prime} N_{q}^{*}$} & \multirow[b]{2}{*}{$\begin{array}{c}q_{s}=c^{\prime}+(1-\sin \phi) \sigma_{v, \text { imean }}^{\prime} \tan \phi^{\prime} \\
\sigma_{v, i \text { mean }}^{\prime}-\text { average value of effective } \\
\text { vertical stress in soil layer }\end{array}$} \\
\hline & $\begin{array}{c}\mathrm{N}_{\mathrm{c}}^{*}, \mathrm{~N}_{\mathrm{q}}^{*} \text { - factors for unit } \\
\text { tip resistance calculated } \\
\text { according to Meyerhof } \\
\qquad \eta=1-\sin \phi^{\prime}\end{array}$ & $\begin{array}{c}\text { Prema Hansen-u: } \\
N_{q}^{*}=N_{q} d_{q} \\
N_{c}^{*}=N_{c} d_{c} \\
N_{q}=e^{\pi \tan \phi^{\prime}\left[\tan \left(45^{\circ}+\frac{\phi^{\prime}}{2}\right)\right]^{2}} \\
N_{c}=\left(N_{q}-1\right) \cot \phi^{\prime} \\
d_{q}=1+2 \tan \phi^{\prime}\left(1-\sin \phi^{\prime}\right)^{2} \arctan \frac{D_{f}}{B} \\
d_{c}=1+0,4 \arctan \frac{D_{f}}{B} \\
\eta=1,0\end{array}$ & \\
\hline
\end{tabular}


The second group of investigated piles consisted of Franki piles, constructed at four locations in Serbia. The Franki pile is a driven, cast-in-situ concrete displacement pile with an enlarged dry concrete base and a cylindrical shaft. Seven test piles were constructed as a part of the Serbian wind turbine park projects "Košava", "Malibunar", and "Alibunar" [20-22], while one was constructed for the Univerexport shopping mall project in Novi Sad [23]. Piles were $520 \mathrm{~mm}$ in diameter and ranged from 14 to 16 $\mathrm{m}$ in length. At all locations, static pile loading was conducted by the IMS Institute according to ASTM D1143 [24]. The ballast was made of concrete blocks, with the maximum weight exceeding the prescribed force by $10 \%$. The force was applied in increments, each amounting to $10 \%$ of the prescribed force. The settlement was measured with an accuracy of $0.01 \mathrm{~mm}$. At each load increment, the load was maintained at a constant value until consolidation was reached, but not longer than 4 hours. The maximum load for each pile was 1.5 times the design load. In order to determine the ultimate pile capacity, pile head load-displacement curve was approximated by a hyperbola. The Chin [25] extrapolation was used and ultimate load was adopted as the asymptotic value of the hyperbola. Investigated pile data are summarized in Table 3.
Table 3. Characteristics of investigated piles

\begin{tabular}{|c|c|c|c|c|}
\hline \multirow{2}{*}{ Location } & $\begin{array}{c}\text { Pile } \\
\text { type }\end{array}$ & $\begin{array}{c}\text { Pile size } \\
{[\mathrm{mm}]}\end{array}$ & $\begin{array}{c}\text { Length } \\
{[\mathrm{m}]}\end{array}$ & $\begin{array}{c}\text { Num. } \\
\text { of piles }\end{array}$ \\
\cline { 1 - 3 } Belgrade & \multirow{2}{*}{ MEGA } & $400 \times 400$ & $6.25-9.85$ & 16 \\
\cline { 4 - 5 } & & $\varnothing 323$ & 10.0 & 1 \\
\hline Zemun (Belgrade) & & & 16.0 & 2 \\
\hline Zagajica & \multirow{2}{*}{ Franki } & $\varnothing 520$ & 16.0 & 1 \\
\cline { 1 - 1 } Alibunar & & & 14.0 & 3 \\
\cline { 1 - 1 } Malibunar & & & $14.0-15.0$ & 2 \\
\hline
\end{tabular}

\section{Soil profiles}

Soil profiles for each location were defined based on in-situ CPT results [26], and laboratory testing of borehole samples. Six locations in Serbia were selected: Belgrade (Faculty of Chemistry), Zemun (Church), Zagajica, Malibunar, Alibunar (wind turbine park projects), and Novi Sad (Univerexport

Table 4. Soil parameters

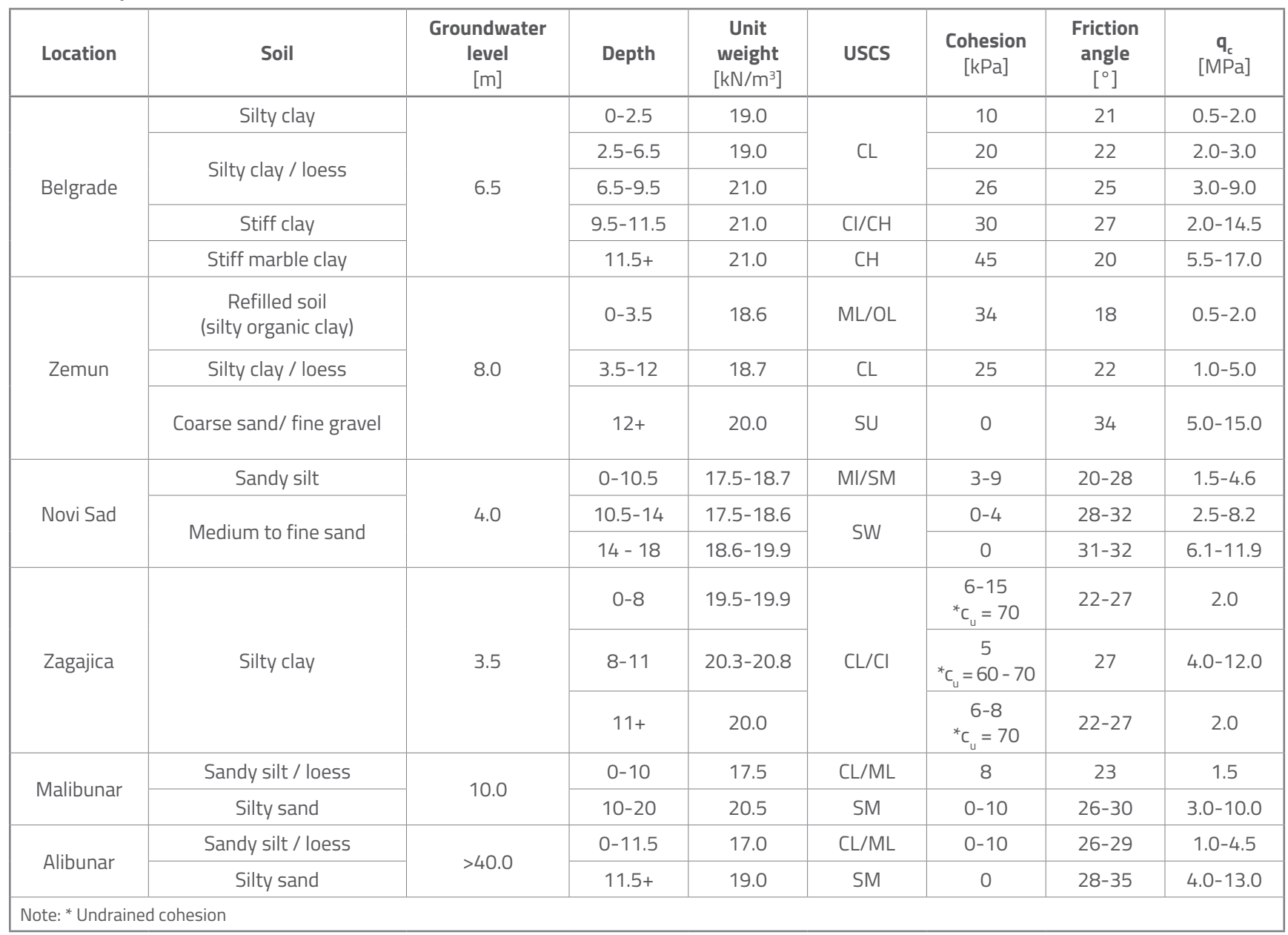


shopping mall). All geotechnical data were taken from the available project documentation [17-23]. At Novi Sad, Alibunar, and Malibunar locations, the pile base goes through silty sand or fine sand. Due to the fact that more than $2 / 3$ of the pile goes through fine grained soil, it is considered that all investigated cases are appropriate for this study. Summary of soil parameters for each location is given in Table 4.

\section{Statistical analyses}

Appropriate statistical methods were used by various authors to evaluate accuracy of pile capacity prediction methods $[1,3,4,27,28]$. The most illustrative parameter for method accuracy checking is the $Q_{p} / Q_{m}$ ratio, which can theoretically range from zero to an unlimited upper value, with an optimum value of one. Values below one mean underprediction, and higher values mean overprediction of pile load capacity.

Arithmetic mean $(\mu)$ and standard deviation $(\sigma)$ of the $Q_{p} / Q_{m}$ ratio are main statistic parameters for assessment of prediction methods. In an idealized case, $\mu\left(Q_{p} / Q_{m}\right)$ equals to one and $\sigma\left(Q_{p}\right)$ $Q_{m}$ ) equals to zero, which means that the method is fully accurate which, in reality, is not the case.

Distribution of $Q_{p} / Q_{m}$ ratio around the mean is, in general, non-symmetric. Therefore, Briaud \& Tucker [1] have suggested the use of log normal distribution for assessing reliability of methods. The log normal distribution is defined with the following probability density function:

$f(x) \frac{1}{\sqrt{2 \pi} \sigma_{\ln } x} \exp \left[-\frac{1}{2}\left(\frac{\ln (x)-\mu_{\ln }}{\sigma_{\ln }}\right)^{2}\right]$

where $x=Q_{p} / Q_{m}$ is the random variable, $\mu_{n}$ is the mean of $\ln \left(Q_{p} / Q_{m}\right)$, and $\sigma_{\text {In }}$ is the standard deviation of $\ln \left(Q_{p}\right)$ $\left.Q_{m}\right)$. The probability density function can be used to calculate probability of predicting the pile load capacity with desired accuracy. Prediction probability
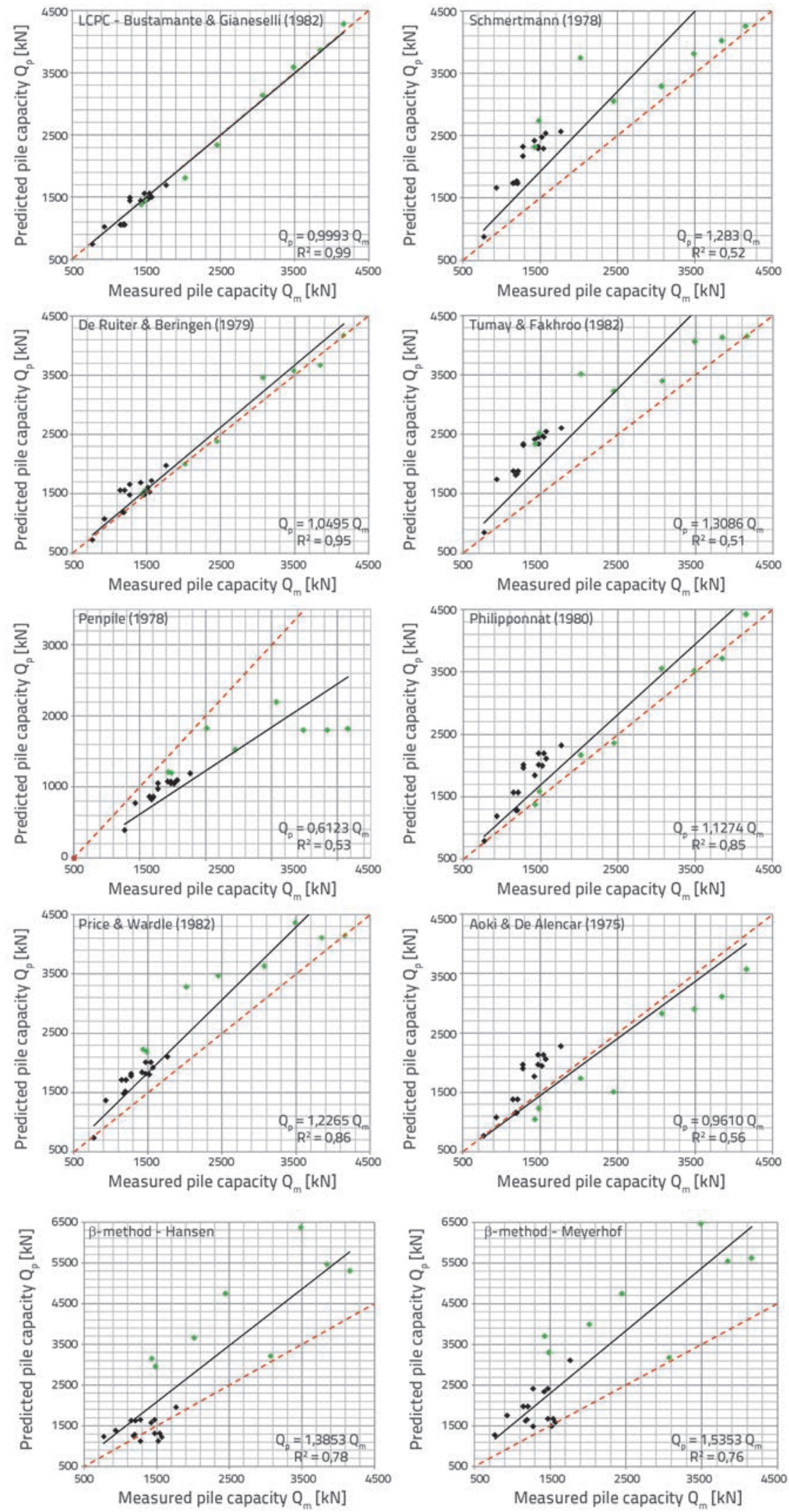

Figure 1. Predicted vs. measured ultimate pile capacity $\left(Q_{p} / Q_{m}\right)$ 
at desired accuracy level is calculated as an area under the probability density function within accuracy limits. For example, probability of predicting the load capacity at $20 \%$ accuracy is an area under the probability density function within the limits of $0.8 \leq \mathrm{Q}_{\mathrm{p}}$ ' $\mathrm{Q}_{\mathrm{m}} \leq 1.2$. For the purpose of this study, an accuracy level of $20 \%$ was adopted, which is in line with proposals made by other authors [4]. In this paper, the following three criteria are used to evaluate prediction methods:

- equations of the best fit lines (trend lines) between measured and predicted pile capacity $\left(Q_{p} / Q_{m}\right.$ ratio) with the corresponding coefficient of determination $\mathrm{R}^{2}$,

- arithmetic mean and standard deviation of $Q_{p} / Q_{m}$ ratio,

- prediction probability for an adopted accuracy level of $20 \%$, using log normal distribution of $Q_{p} / Q_{m}$

\subsection{Statistical analysis results}

The best fit lines of the $Q_{p} / Q_{m}$ ratios are given in Figure 1 for all evaluated methods. The corresponding trendline equations, and the coefficient of determination $\left(R^{2}\right)$ based on regression analysis, are given in each plot. The perfect fit line $\left(Q_{p} / Q_{m}=1\right)$ is plotted as a dashed red line. The results for Franki piles and MEGA piles are plotted as green dots and black dots, respectively. Histograms and log normal distributions for $Q_{p} / Q_{m}$ are given in Figures 2-3 for evaluated methods. Prediction probabilities for different accuracy levels are plotted in Figure 4. Statistical analysis results are summarized in Table 5.

The data show that the Bustamante \& Gianeselli (LCPC) method provides the best match between the measured and estimated pile load capacities. This conclusion is based on the fact that the $Q_{\text {fit }} / Q_{m}$ ratio is close to one (0.9993), and that the coefficient of determination is high $\left(R^{2}=0.99\right)$. This method also has the highest prediction probabilities for different accuracy levels.
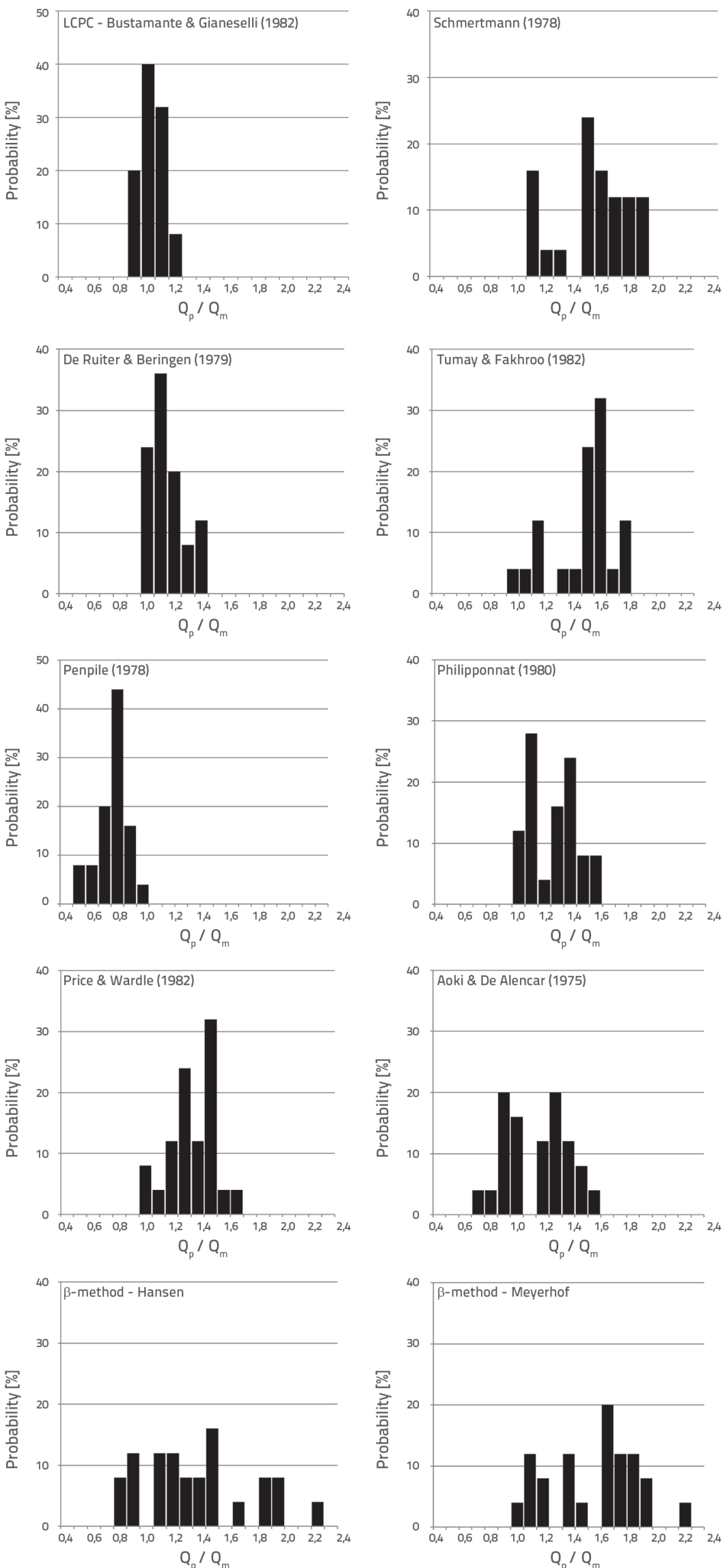

Figure 2. Histogram distribution of $Q_{p} / Q_{m}$

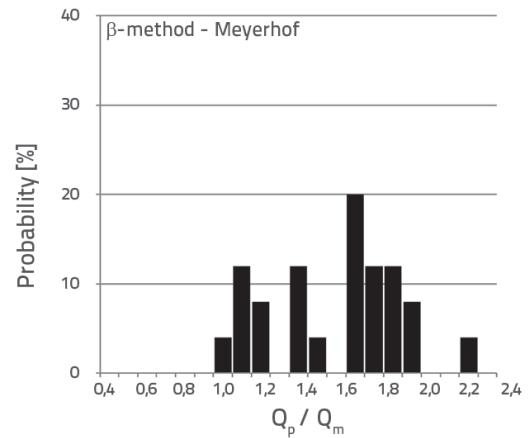


According to evaluation results, De Ruiter \& Beringen method is the "second best" method. Its $\mathrm{Q}_{\mathrm{fit}} / \mathrm{Q}_{\mathrm{m}}$ ratio is also close to one (1.0495), with slight overprediction and smaller coefficient of determination $\left(R^{2}=0.95\right)$ compared to the LCPC method. Prediction probabilities are relatively high. It is important to note that these results were obtained using the corrected value of the correlation factor $N_{k}$ instead of the values recommended in the original paper [16]. A more detailed explanation is given in the discussion.

The Aoki \& De Alencar method with the $\mathrm{Q}_{\mathrm{fit}} / \mathrm{Q}_{\mathrm{m}}$ ratio of 0.9610 is close to the Bustamante \& Gianeselli (LCPC) method, but with the significantly lower accuracy $\left(R^{2}=0.56\right)$ and prediction probability $\left(\mathrm{P}_{20 \%}=31.4 \%\right)$.

Penpile method underpredicts the measured values by about 40 $\%\left(Q_{\text {fit }} / Q_{m}=0.6123\right)$, with a low coefficient of determination $\left(R^{2}=\right.$ $0.53)$ and prediction probabilities.

Other direct CPT prediction methods significantly overestimate the pile load capacities (up to $31 \%$ higher prediction values compared to measured ones), with various coefficients of determination (0.51-0.86). Philipponnat and Price \& Wardle methods have better prediction probabilities $\left(P_{20 \%} \sim 32-34\right.$ $\%)$ in comparison with Schmertmann and Tumay \& Fakhroo methods $\left(P_{20 \%} \sim 23-24 \%\right)$. Effective stress analysis $(\beta)$ methods show overprediction of $39-54 \%$, with acceptable coefficient of determination of 0.76-0.78.

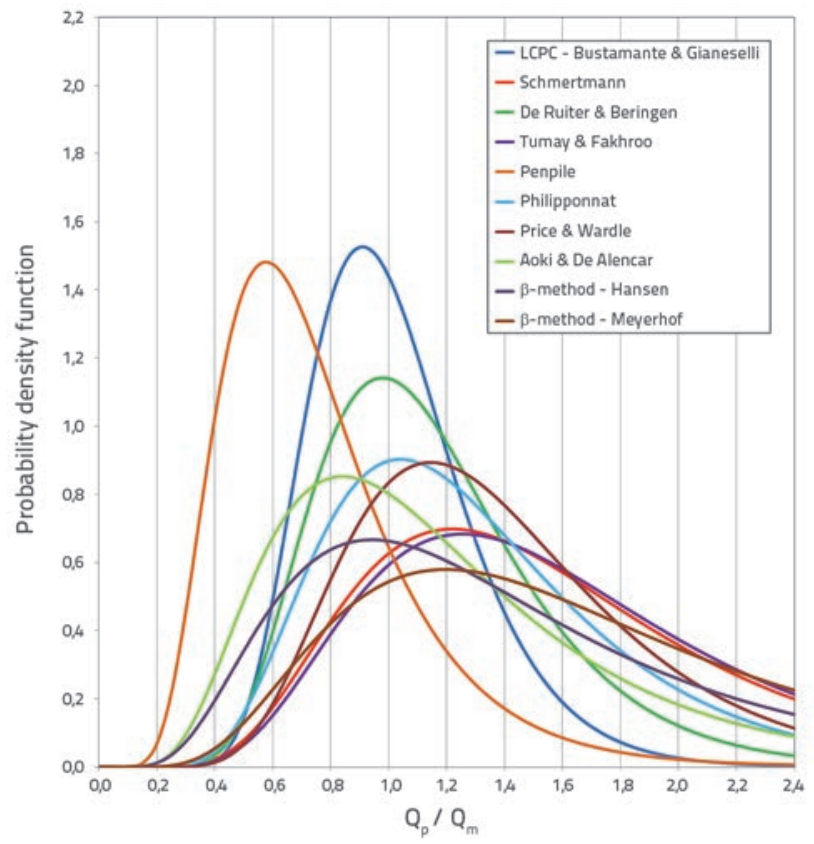

Figure 3. Log normal distribution of $Q_{p} / Q_{m}$ for evaluated methods

In order to analyse the influence of draining conditions, the static $\alpha$-method (API method) [15] was additionally used to calculate bearing capacities of the piles for which the undrained shear strength soil parameters were available (Zagajica). The corresponding results are given in Table 6 . An average $Q_{p} / Q_{m}$ ratio is around 1.05 , which is very close to one.

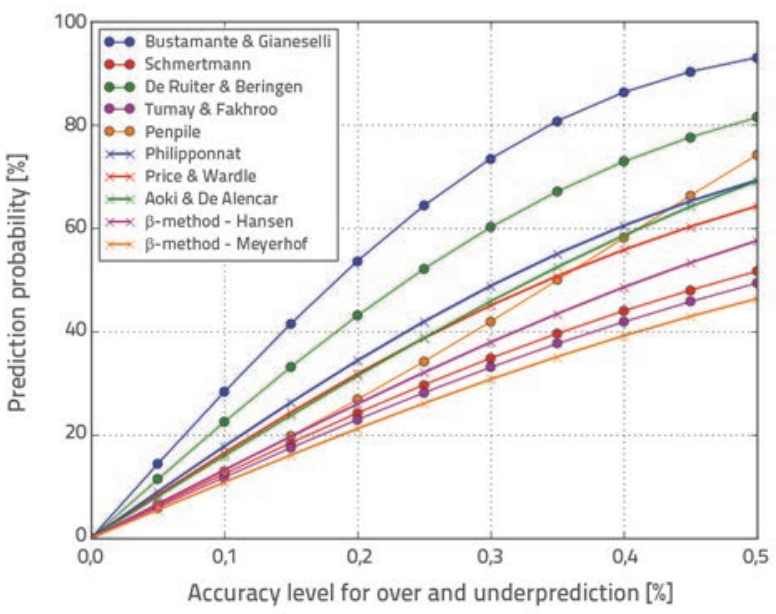

Figure 4. Estimation accuracy vs. probabilities for different prediction methods

Table 5. Results of statistical assessment of different prediction methods

\begin{tabular}{|c|c|c|c|c|c|}
\hline \multirow{2}{*}{$\begin{array}{l}\text { Prediction } \\
\text { method }\end{array}$} & \multicolumn{2}{|c|}{ Best fit line } & \multicolumn{2}{|c|}{$\begin{array}{c}\text { Arithmetic } \\
\text { mean / } \\
\text { standard } \\
\text { deviation }\end{array}$} & \multirow{2}{*}{$\begin{array}{c}\begin{array}{c}\text { Prediction } \\
\text { probability }\end{array} \\
\pm 20 \% \\
\text { Accuracy [\%] }\end{array}$} \\
\hline & $\begin{array}{c}\mathrm{Q}_{\mathrm{fit}} / \mathrm{Q}_{\mathrm{m}} \\
\text { ratio }\end{array}$ & $\mathrm{R}^{2}$ & $\mu$ & $\sigma$ & \\
\hline $\begin{array}{l}\text { Bustamante } \\
\& \text { Gianeselli } \\
\text { (LCPC) }\end{array}$ & 0.9993 & 0.99 & 0.984 & 0.077 & 53.6 \\
\hline Schmertmann & 1.2830 & 0.52 & 1.487 & 0.254 & 24.2 \\
\hline $\begin{array}{l}\text { De Ruiter \& } \\
\text { Beringen }\end{array}$ & 1.0495 & 0.95 & 1.103 & 0.130 & 43.1 \\
\hline $\begin{array}{l}\text { Tumay \& } \\
\text { Fakhroo }\end{array}$ & 1.3086 & 0.51 & 1.525 & 0.251 & 23.0 \\
\hline Penpile & 0.6123 & 0.53 & 0.702 & 0.116 & 26.8 \\
\hline Philipponnat & 1.1274 & 0.85 & 1.228 & 0.188 & 34.4 \\
\hline $\begin{array}{l}\text { Price \& } \\
\text { Wardle }\end{array}$ & 1.2265 & 0.86 & 1.318 & 0.169 & 31.8 \\
\hline $\begin{array}{l}\text { Aoki \& De } \\
\text { Alencar }\end{array}$ & 0.9610 & 0.56 & 1.102 & 0.255 & 31.4 \\
\hline $\begin{array}{l}\beta \text {-method } \\
\text { (Meyerhof) }\end{array}$ & 1.3853 & 0.78 & 1.325 & 0.398 & 26.0 \\
\hline $\begin{array}{c}\beta \text {-method } \\
\text { (Hansen) }\end{array}$ & 1.5353 & 0.76 & 1.594 & 0.399 & 21.2 \\
\hline
\end{tabular}

Table 6. Pile load capacities predicted using $\alpha$-method

\begin{tabular}{|c|c|c|c|c|}
\hline \multirow{2}{*}{ Location } & $\begin{array}{c}\text { Pile } \\
\text { type }\end{array}$ & $\mathbf{Q}_{\mathbf{m}}[\mathrm{kN}]$ & $\mathbf{Q}_{\mathbf{p}}[\mathrm{kN}]$ & $\mathbf{Q}_{\mathbf{p}} / \mathbf{Q}_{\mathbf{m}}$ \\
\hline \multirow{2}{*}{ Zagajica } & $\begin{array}{c}\text { Franki } \\
\varnothing 520\end{array}$ & 1430 & 1515.07 & 1.059 \\
\cline { 3 - 5 } & 1482 & 1529.86 & 1.032 \\
\hline
\end{tabular}




\section{Discussion}

Correlation factors for the current CPT methods are calibrated using a limited amount of load test data and usually for specific local geological conditions. Additionally, CPT data used in the derivation of correlation factors is based on the results of less reliable mechanical penetrometers, as no other penetrometer types were available at the time of method development. For most methods, the choice of correlation factors is not precisely defined, which increases uncertainty of the methods. It is also common to most of the methods to impose limitations in terms of maximum unit resistance of the base and the shaft, which is considered to be an unjustified approach by many recent studies. All these factors affect prediction of the axial load capacity of piles, depending on the type of piles and the type of soil.

According to the results of the study, the Bustamante \& Gianeselli (LCPC) method is the most appropriate method for prediction of load capacities of the Franki and MEGA piles under local geotechnical conditions. Compared to other methods, this method defines more accurately correlation factors that depend on the type of piles, soil types, and cone resistance values.

The "second best" De Ruiter \& Beringen method is considered appropriate for use in the analysed geotechnical conditions, provided that corrected correlation factors $\mathrm{N}_{\mathrm{k}}$ are used. The uncertainty of the De Ruiter \& Beringen method primarily arises from the correlation between the cone resistance and undrained shear strength. Results obtained by other authors [16] show that the $N_{k}$ coefficient varies over a much wider range than suggested by the authors of the original paper $\left(N_{k}=15-\right.$ 20). Essentially, this method is based on the undrained strength and corresponds more to the $\alpha$-methods than the direct CPT methods.

The Aoki \& De Alencar method is close to Bustamante \& Gianeselli (LCPC) method but is considered unreliable because of significant scattering of results. The Penpile method underpredicts load capacity of piles, which is in line with the results of other authors [4, 29], who have also found that this method is conservative.

Other direct CPT prediction methods significantly overestimate pile load capacities, with trend lines generally ranging from 1.13 (Philipponnat) to 1.31 (Tumay \& Fakhroo). Schmertmann, Tumay \& Fakhroo and Price \& Wardle methods are not ideal for the considered geotechnical conditions, mostly because of overestimated values of shaft resistance.

The $\beta$-methods overestimate pile load capacities (Hansen more than Meyerhof), because of the fact that they are based on the effective stress analysis. Fully drained conditions were not met in the case under study. The scattering of results is probably the consequence of inaccuracy of the design geotechnical profile adopted in geotechnical reports [17, 20-23].

A small statistical sample was available for estimation of the $\alpha$-method, and so a reliable evaluation proved impossible. However, the results point to the conclusion that the use of the $\alpha$-method is justified in the case of undrained conditions, i.e. for saturated clayey soil. Furthermore, in the authors' experience, there is a good agreement between the prediction of pile load capacity based on the LCPC method (evaluated as the most appropriate one) and the $\alpha$-method, which is in line with the preceding conclusion.

The results of the study have shown that most direct CPT methods better predict load capacity of Franki piles compared to MEGA piles. The explanation of such results lies in the interpretation of the measured ultimate pile capacity of MEGA piles. Namely, the technology of MEGA piles, as well as the project progress schedule, did not allow the time period of more than $48 \mathrm{~h}$ between the end of pile installation and the jacking force measurement. Considering the fact that the soil profile consists mainly of silty clays, it is assumed that the mentioned time period was not sufficient to complete the process of dissipation of the excess pore pressures generated during pile installation. This prevented mobilisation of maximum pile axial resistance, which is assumed to be at least $10-20 \%$ higher [29, 30]. The authors of the paper have decided not to correct the measured force based on the mentioned factors, considering that the measured jacking force is the short-term (minimum) pile capacity.

\section{Conclusions}

This paper presents the evaluation of methods for predicting the ultimate bearing capacity of single piles, mostly in cohesive soils, based on the cone penetration test (CPT) results, as well as according to static methods based on the effective and total stress analysis. Seventeen jacked-in MEGA piles and eight Franki piles of various lengths were considered. Static pile load tests were used to measure load capacity of Franki piles, while the final pile jacking force was used as the measured capacity of MEGA piles.

Several conclusions can be made based on results presented in this study. For direct CPT methods, main factors influencing the disagreement between predicted and measured pile load capacities are imperfections of CPT prediction methods and interpretation of pile load test results.

Among the direct CPT methods evaluated in the paper, the Bustamante \& Gianeselli (LCPC) method remains the most appropriate method for the considered soil type and pile types, and can be recommended for use in routine engineering practice. The "second best" De Ruiter \& Beringen method can be considered reliable for use in geotechnical conditions under study, but a very careful selection of the corrected correlation factors $N_{k}$ is nevertheless necessary. Penpile method significantly underpredicts the load capacity of piles, which is why it can be described as highly conservative. The Price \& Wardle, Schmertmann and Tumay \& Fakhroo methods significantly overpredict the axial pile capacity, and are therefore unsuitable for the considered geotechnical conditions.

The Meyerhof and Hansen $\beta$-methods overestimate the pile load capacities because they are based on the effective stress analysis, which does not correspond to undrained conditions for saturated clayey soil. The study points to the conclusion that $\alpha$-method is an appropriate method for predicting capacity of piles in the considered saturated clayey soils. 


\section{REFERENCES}

[1] Briaud, J.L., Tucker, L.M.: Measured and predicted axial response of 98 piles, Journal of Geotechnical Engineering, 114 (1988) 9, pp. 984-1001.

[2] Sharp, M.R., McVay, M.C., Townsend, F.C., Basnett, C.R.: Evaluation of pile capacity from in situ tests, Proceedings of the Symposium on Soil Properties-Evaluation from Centrifugal Models and Field Performance at ASCE National Convention, Nashville, pp. 134156, 1988.

[3] Eslami, A., Fellenius, B.H.: Pile capacity by direct CPT and CPTu methods applied to 102 case histories, Canadian Geotechnical Journal, 34 (1997) 6, pp. 886-904.

[4] Abu-Farsakh, M.Y., Titi, H.H.: Assessment of direct cone penetration test methods for predicting the ultimate capacity of friction driven piles, Journal of Geotechnical and Geoenvironmental Engineering, 130 (2004) 9, pp. 935-944.

[5] Bustamante, M., Gianeselli, L.: Pile Bearing Capacity Prediction by Means of Static Penetrometer CPT, Proceedings of the $2^{\text {nd }}$ European Symposium on Penetration Testing, Amsterdam, pp. 493-500, 1982.

[6] Schmertmann, J.H.: Guidelines for Cone Penetration Test, Performance and Design, Rep. No. FHWA-TS-78-209, Washington D.C., 1978.

[7] De Ruiter, J., Beringen, F.L.: Pile foundations for large North Sea structures, Marine Georesources \& Geotechnology, 3 (1979) 3, pp. 267-314.

[8] Tumay, M.T., Fakhroo, M.: Friction pile capacity prediction in cohesive soils using electric quasi-static penetration tests, Interim Research Rep. No. 1, Louisiana Department of Transportation and Development, Baton Rouge, Louisiana, 1982.

[9] Clisby, M.B., Scholtes, R.M., Corey, M.W., Cole, H.A., Teng, P., Webb, J.D.: An evaluation of pile bearing capacities, Volume I, Final Report, Mississippi State Highway Department, 1978.

[10] Philipponnat, G.: Methode pratique de calcul d'un pieu isole a l'aide du penetrometre statique, Rev. Fr. Geotech.,10, pp. 55-64, 1980.

[11] Price, G., Wardle, I.F.: A comparison between cone penetration test results and the performance of small diameter instrumented piles in stiff clay, Proceedings of the $2^{\text {nd }}$ European Symposium on Penetration Testing, Amsterdam, pp. 775-780, 1982.

[12] Aoki, N., de Alencar, D.V.: An approximate method to estimate the bearing capacity of piles, Proc. $5^{\text {th }}$ Pan-American Conf. of Soil Mechanics and Foundation Engineering, Buenos Aires, 1 (1975), pp. 367-376.

[13] Meyerhof, G.G.: Bearing Capacity and Settlement of Pile Foundations, Journal of Geotechnical and Geoenvironmental Engineering, 102 (1976), pp. 195-228.

[14] Bowles, J.E.: Foundation analysis and design (5th edition), McGrawHill, 1997.
[15] American Petroleum Institute: API Recommended Practice for Planning, Designing and Constructing Fixed Off-shore Platforms, API, Washington D.C., 1984.

[16] Briaud, J.L.: Geotechnical engineering: unsaturated and saturated soils, John Wiley \& Sons, 2013.

[17] Report on the findings of the causes of settlements of the building of Faculty of Chemistry in Belgrade (In Serbian), Kosovoprojekt, Belgrade, 1974.

[18] Main design of rehabilitation of the foundations of Faculty of Chemistry in Belgrade (In Serbian), University of Belgrade Faculty of Civil Engineering, Belgrade, 2008.

[19] Main design of rehabilitation of St. Nicholas church structure in Zemun, University of Belgrade - Faculty of Civil Engineering, Belgrade, 2010.

[20] Report on geotechnical investigation with foundation conditions for wind turbine generators VG1-VG39, wind park "Košava", University of Belgrade - Faculty of Civil Engineering, Belgrade, 2012.

[21] Geotechnical report for the needs of the Main design of wind power plant "Malibunar" (In Serbian), Geoput, Belgrade, 2013.

[22] Geotechnical report for the needs of the Main design of wind power plant "Alibunar" (In Serbian), Geoput, Belgrade, 2013.

[23] Geotechnical report for the needs of design of the new distribution center with internal supporting roadways "Univerexport" in Novi Sad (In Serbian), GT Inženjering, Belgrade, 2015.

[24] ASTM D1143: Standard test methods for deep foundations under static axial compressive load, ASTM International, 2013.

[25] Chin, F.K.: Estimation of the ultimate load of piles from tests not carried to failure, Proceedings of the Second Southeast Asian Society of Soil Engineering, Singapore, pp. 81-90, 1970.

[26] Librić, L., Jurić-Kaćunić, D., Kovačević, M.S.: Application of cone penetration test (CPT) results for soil classification, GRAĐEVINAR, 69 (2017) 1, pp. 11-20.

[27] Long, J.H., Wysockey, M.H.: Accuracy of methods for predicting axial capacity of deep foundations, Proc. OTRC '99 Conf.: Analysis, Design, Construction, and Testing of Deep Foundations, GSP No. 88, Reston, pp. 190-195, 1999.

[28] Cai, G., Liu, S., Tong, L., Du, G.: Assessment of direct CPT and CPTU methods for predicting the ultimate bearing capacity of single piles. Engineering Geology, 104 (2009) 3, pp. 211-222.

[29] Brown, R.P.: Predicting the ultimate axial resistance of single driven piles, PhD thesis, University of Texas, 2001.

[30] Yu, F., Kou, H., Liu, J., Yang, Y.: Jacking installation of displacement piles: from empiricism toward scientism. Electronic Journal of Geotechnical Engineering, 12 (2012), pp. 1381-1390. 